\title{
Factors Influencing Assessment Practices among University Academic Staff: A Multiple Regression Analysis
}

\author{
Musa Matovu* \\ Institute of education, International Islamic University Malaysia, Kuala Lumpur, Malaysia
}

\begin{tabular}{|c|c|}
\hline \multicolumn{2}{|c|}{$\begin{array}{l}\text { Ainol Madziah Zubairi } \\
\text { Institute of education, International Islamic University Malaysia, Kuala Lumpur, Malaysia }\end{array}$} \\
\hline Article history & This study investigated the factors influencing assessment practices \\
\hline $\begin{array}{l}\text { Received: } \\
06.08 .2013\end{array}$ & $\begin{array}{l}\text { among academic staff in universities, in Uganda. Academic levels, type } \\
\text { of the university, specialisation, class size, and assessment-based training }\end{array}$ \\
\hline $\begin{array}{l}\text { Received in revised form: } \\
14.03 .2014\end{array}$ & $\begin{array}{l}\text { were hypothesised as factors influencing the university academic staff's } \\
\text { assessment practices. A purely quantitative approach was adopted to } \\
\text { collect and analyse data for this study. An Assessment Practice Inventory }\end{array}$ \\
\hline $\begin{array}{l}\text { Accepted: } \\
18.03 .2014\end{array}$ & $\begin{array}{l}\text { Modified scale was used to collect data from } 321 \text { university academic } \\
\text { staff considering their categorisations. Using multiple regression analysis, }\end{array}$ \\
\hline Key words: & out of the five predictors included in the model academic levels and \\
\hline $\begin{array}{l}\text { Assessment practices, } \\
\text { university academic staff, } \\
\text { multiple regression analysis }\end{array}$ & $\begin{array}{l}\text { assessment-based training were found to be significant predictors of the } \\
\text { university academic staff's assessment practices; }(\mathrm{F}[2,310]=46.331 \text {, } \\
<.001) \text {. According to the results revealed in this study, it is } \\
\text { recommended that universities should ensure that their academic staff } \\
\text { rise in academic levels and also, they should provide them with } \\
\text { assessment-based training to improve their competencies and skills in } \\
\text { assessing students. }\end{array}$ \\
\hline
\end{tabular}

\section{Introduction}

Assessment is a logical approach of gathering data about students' academic progress in order to improve on the student learning and the learning process (Cartwright, et al., 2009; Ewell, 2009; Lindholm, 2009; Marsh, 2007; Scroggins, 2004). Assessments clarify on what students have learnt and also, act as accountability points in the learning process (Alkharusi, 2011, 2012; Koh, 2011; Phamotse et al., 2011). In the process of assessing students, teachers use various approaches to understand what the students have learnt in relation to the curriculum expectations (Harlen, 2005; Timperley, Wilson et al., 2007). Assessments in learning are undertaken on individual students or groups, in form of formative or summative evaluation, or as standardised or informal assessments. In general, assessments provide evidence about the learning outcomes, learning process, individual students, institutions, and programmes to the teachers, students, administrators, and other education stakeholders (Mundia, 2010).

There are different types of assessments which have been highlighted in the various studies. The type of assessments include; assessment for learning, assessment of learning, and assessment as learning. Assessment for learning can be equated to formative assessment in learning. Assessment for learning is used to collect information about the learning process and individual students during the learning process for improvement purposes (Black \& Wiliam, 1998). Also, assessment for learning helps students to revisit their mistakes, learn from their peers and their past experiences to improve their learning and learning environment (Black, et al., 2004; Boston, 2002; Duncan \& Noonan, 2007; Rolheiser \& Ross, 2000). In assessment for learning, consecutive assessments are undertaken onto the

\footnotetext{
* Corresponding author: Musa Matovu, matovumousa@yahoo.com
} 
students across the study period of a given course (Nicol \& MacFarlane-Dick 2006; Swaffield, 2011).

Assessment of learning is equivalent to summative assessment when it is used in the learning process. Assessment of learning is a single shot appraisal that involves examining what the students have learnt and the study programme at the end of a given course(s). Assessment of learning is used to understand whether the students have attained the required knowledge in totality at end the course(s) they have undertaken (Gipps, 1994). Assessment as learning involves students making self-assessment on themselves (McDowell et al., 2011). Students engage in personal evaluation of their learning and also, use the obtained information to improve their learning and academic career. Assessment as learning helps the students to discover their own mistakes and also, learn from their peers in order to improve their learning (Earl, 2003).

According to the different studies conducted in assessment and assessment practices, several factors have been mentioned to influence the academic staff's assessment practices (Duncan \& Noonan, 2007). The factors which have been highlighted to influence the academic staff's assessment practices in the different studies include academic levels, subject or area of specialisation, class size, type of university, and assessment-based training acquired by the academic staff (Duncan \& Noonan, 2007).

\section{Literature Review}

\section{Academic levels}

According to research that has been conducted in assessment it has been mentioned that academic levels or academic staff qualifications influence their assessment practices (Noordin \& Jusoff, 2009). Progressing through academic levels is linked to experience which can influence the assessment practices of the academic staff at the university level. It is mentioned in some studies that academic staff assessment practices can improve if the academic staff have consecutive interactions with assessing students (Sato et al., 2008). The continuous interaction with assessments gives an advantage to the academic staff who have taught for a longer period of time, with more experience, and high academic levels to have good assessment practices (Masole, 2011; Sato et al., 2008). On the other side, other studies have highlighted that academic levels do not influence academic staff's assessment practices (Masole, 2011). This highlights a gap of conclusive research about assessment practices among university academic staff according to their academic levels.

\section{Area of Specialisation}

Efficiency in assessment is influenced by subject area or specialisation of the academic staff (Dunca \& Noonan, 2007). According to Dunca and Noonan (2007) subject specialisations have a lot to explain in the assessment practices of the academic staff. On the other hand, Susuwele-Banda (2005) highlighted that academic staff's areas of specialisation did not contribute to the academic staff's assessment practices. In some studies it is highlighted that there are differences in assessment practices of the academic staff according to their different areas of specialisation or qualifications (Adams \& Hsu, 1998; Bol et al., 1998; Koloi-Keaikitse, 2012; Stiggins \& Conklin, 1992), while others disagree that the differences do not exist (Dunca \& Noonan, 2007). The differences in assessment practices among the academic staff have been much highlighted between the academic staff in the specialisations of science and arts subjects (McMillan, 2003; Stiggings \& Conklin, 1992).

\section{Class Size}

From the studies done on assessment practices, academic staff's assessment practices have been inclined to the nature of class sizes assessed (Black \& Wiliam, 1998; Dunca \& Noonan, 2007; Koloi-Keaikitse, 2012; Monk \& Haller, 1993; Susuwele-Banda, 2005). Studies done in assessment highlight that the nature of class size influences the way the academic staff assess their students 
(Gibbs \& Simpson, 2004; Masole, 2011). Large class sizes in assessment are viewed as a threat to the quality of assessments on the side of the teacher and might result into misconducts on the side of the students. In the different studies done in assessment, teachers have acknowledged that they assess large classes which makes them assess poorly the students they teach (Masole, 2011). Class size reduction has been mentioned as one of the ways which can improve student assessment and their learning (Graue et al., 2007; Susuwele-Banda, 2005). This is because large class sizes lead to poor use of assessment equipment and materials, giving of general marks to students, lack of concentration by lecturers when assessing, crisis of time on the side of the lecturers, inadequacy of tools and resources, and development of negative attitudes by the lecturers on the side of assessment (Masole, 2011).

Classes appropriate for good assessment and performance of students need to be sizable or, small in number for lecturers to adequately handle the assessments (Finn et al., 2003; Jones, 2006; Masole, $2009,2011)$. In situations where the classes are too big, they should be reduced to smaller classes which lecturers can handle effectively when assessing students (Bennel \& Molwane, 2008; SusuweleBanda, 2005). This would give lecturers room to attend to students individually during the instruction process and also, to adequately assess and grade their work during the assessment process (McMillan, 2003; Miller et al., 2007). On the other hand, some studies have mentioned that there is a negative relationship between class size and assessment practices (Duncan \& Noonan, 2007; Locastro, 2001; Reynolds et al., 2001; Welsh, 1989). The contradicting finding on whether class size influences academic staff's assessment practices or not, highlights lack of grounded studies on the relationship between class size and assessment practices (Locastro, 2001; Reynolds et al., 2001).

\section{Assessment-Based Training}

Effective assessment of students by the academic staff in any learning institution depends on the quality of assessment training attained in assessing students (Zhang \& Burry-Stock, 2003). Availing assessment training courses are some of the ways in which institutions can equip their academic staff with the required assessment competencies and skills in assessing students (Duncan \& Noonan, 2007; Harlen, 2005; Sato et al., 2008; Tindal \& Haladyna, 2002). Empirical studies that have been undertaken in assessment-based training have highlighted that training influences academic staff's assessment practices (Brookhart, 2003; Duncan \& Noonan, 2007; Guskey, 2003; Masole, 2009; Phamotse et al., 2011; Stiggins, 2002, 1999; Zhang \& Burry-Stock, 2003). Studies have also found that academic staff's possession of good assessment competencies and skills make as the adequate in assessing students (Stiggins, 1999, 2002; Zhang \& Burry-Stock, 2003). Giving an opportunity to academic staff to assess students without proper assessment competencies and skills can be equated to academic suicide in a learning environment (Popham, 2004, 2009). This is because during assessment academic staff undertake critical academic decisions on students and the study programme without the required expertise. In a general analysis of studies done in assessment, it has been highlighted that most of the academic staff in institutions have inadequate competencies and skills in assessing students (Phamotse et al., 2011; Stiggins, 1999; Zhang \& Burry-Stock, 2003).

It has been mentioned in research that academic staff with assessment-based training have better assessment practices than those who have not undertaken any assessment-based training (Masole, 2011). Lecturers who lack adequate competencies and skills in assessing students are likely to have poor assessment practices (Howie, 2006; Stiggins, 2002). In studies which have analysed the assessment competencies and skills of academic staff it was discovered that most academic staff in institutions were incompetent in assessing students and also, a few academic staff had undertaken assessment-based training (Alkharusi, 2011, 2012; Masole, 2011; Phamotse et al., 2011; Zhang \& Burry-Stock, 2003). In universities where majority academic staff train in their professions assessment-based training is optional to students, while in other universities they do not have such training for both students and their lecturers. In such a situation, this highlights that assessment-based training areis not taken as an important issue in these particular institutions (Phamotse et al., 2011), though it is known that assessments are inevitable in the learning process (Pellegrino et al., 2001). It is of great importance that academic staff be equipped with adequate competencies and skills in 
assessing students, that is, in the way they design, administer, interpret, and apply the results obtained from the assessments (Koloi-Keaikitse, 2012). In the different studies done in assessment education stake holders have advocated for assessment-based training to the academic staff in order to improve their assessment practices. This would improve on the way the academic staff assess students in the classrooms (Guskey, 1994, 2003; Stiggins, 1999, 2001, 2002).

\section{Types of University}

In Uganda there are both public and private universities. All the different types of universities operate under the National Council for Higher Education guidelines, which also controls quality in all aspects the universities undertake including student assessment. Although few, public universities admit larger numbers of students compared to private universities. The classes in most of the courses in public universities are relatively larger in number than those in private universities. According to research, large classes are likely to hinder instructors' objectives in meeting students' academic needs in the teaching and assessment process (Dunca \& Noonan, 2007; Reymond et al., 2001). Public universities have more funds and resources, better infrastructure and facilities as they are funded by government than their counterparts. Also, public universities have bigger libraries, modern lecture theatres, better internet facilities and services, bigger research grants and upgrading opportunities for their academic staff. Mainly, private universities depend on private funds raised from students' tuition fees, and sometimes from donor agencies

\section{Purpose of the study}

This study investigated the significant factors influencing assessment practices among academic staff in Ugandan universities. This study has investigated how factors such as academic levels, type of university, specialisation, class size, and assessment-based training influence the assessment practices of the academic staff in universities.

\section{Research Question}

The study was guided by the following research question;

Do academic levels, specialisations, type of university, class size, and assessment-based training predict assessment practices among academic staff in Ugandan universities?

\section{Methods}

This highlights the different approaches used to conduct the study of the factors influencing assessment practices among academic staff in universities. This study adopted a purely quantitative study.

\section{Sample and Sampling techniques}

The data analysed in this study was collected from 321 academic staff randomly selected from four universities. The sample of academic staff was selected from two public and two private universities in consideration of their academic levels (Teaching assistants, assistant lecturers, lecturers, associate professors, and professors) and specialisations (Arts, human sciences, sciences, and education).

\section{Instrument}

An Assessment Practice Inventory Modified questionnaire (Matovu \& Ainol, 2013) which has 13 demographic questions and 50 items on the likert scale was used to collect the data for the study. The 50 items on the likert scale $(1=$ not-at-all-skilled, $2=$ a-little-skilled, $3=$ some-what-skilled, $4=$ 
skilled, $5=$ highly-skilled ) collected information about the academic staff assessment practices while the 13 demographic questions identified the academic staff and also, acted as the predictor variables in the study. According to the results of the Cronbach's alpha coefficients the reliability of the Assessment Practice Inventory Modified was .967, which indicated that it was an excellent instrument in measuring assessment practices among university academic staff (Garson, 1998; Gleim \& Gleim, 2003; Tavakol \& Dennick, 2011).

\section{Data Collection}

Different research assistants were assigned to collect data from the different universities which were selected randomly from their respective cohorts (Private and public) to participate in the study. The research assistants randomly selected academic staff from the different faculties and departments in the selected universities, and distributed the questionnaires to them by hand. Also, in the selection of the academic staff their academic levels, areas of specialization and the sizes of the classes they teach were put into consideration. Whether academic staff had taken an assessment-based training or not, was not considered in selecting them. This method of selecting participants for the study helped in having a representative sample for all the attributes which were under investigation in this study.

\section{Data analysis}

To analyse the data multiple regression analysis was used to find out the amount of gradient equated to the size of the bivariate correlations between the different predictor variables (Academic levels, type of university, specializations, class size, and assessment-based training) and assessment practices. The step-wise method of multiple regression analysis was employed to determine the predictive power of each individual independent variable in model onto assessment practices.

\section{FINDINGS}

\section{Assumption checks}

Multiple regression assumption checks were conducted to examine normality, linearity, multicollinearity, outliers, and independence of errors within the data before the main analysis. For normality, the descriptive statistics of both skewness and kurtosis for the items in the data were in a normal range; between -1.0 and +1.0 . Also, the normal probability plot of the regression standardised residual points approximates a positive straight diagonal line from the left to right verifying the assumption of normality for the errors in the model (Baylor et al., 2010) (Figure 1). This suggests that the data was normal due to the absence of major deviations from the normal, with the data requiring no transformation. The histogram in Figure 2 highlights that some variables are not within a perfect normal distribution, but the mean (2.09E-15) for the distribution is very close to zero which confirms the normality of the data. 


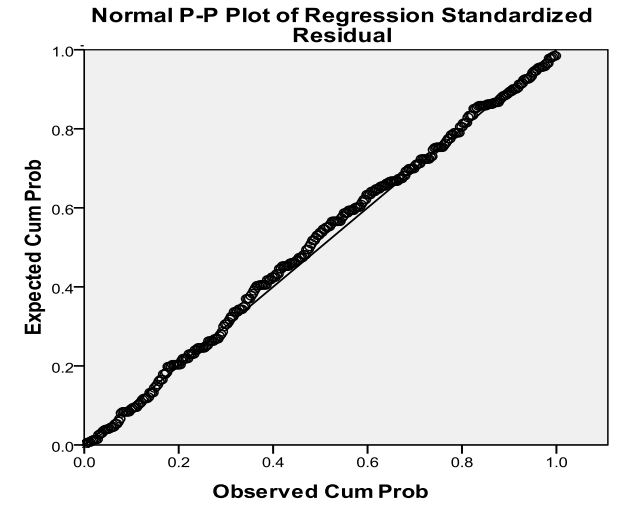

Figure 1. Normal Plot (P-P) for the Regression Standardised Residuals

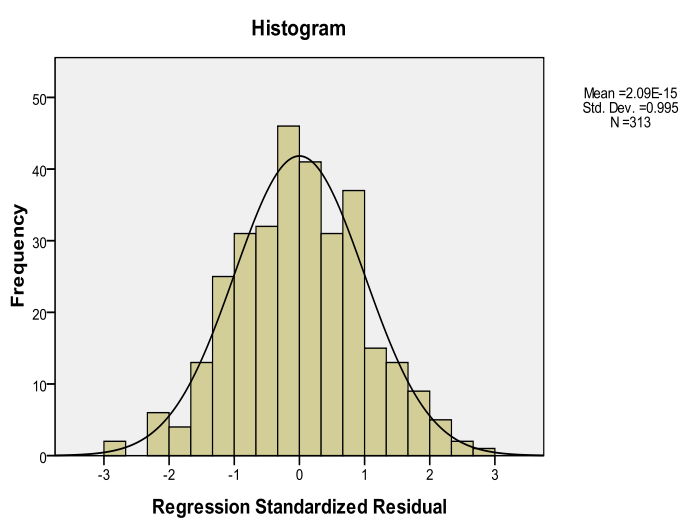

Figure 2. Normal Distribution Curve

Analysing the scatter plot of the regression standardised residuals, most of the errors are located in the centre of the scatter plot (around 0 point) with the residuals approximating a rectangular distribution. This also suggests that the data was normally distributed (Tabachnick \& Fidell, 2007) as seen in Figure 3. In the regression scatter plot, the error terms in the plot are relatively constant to highlight that the error variances are constant with predictor (independent) variables (see Figure 3). This concludes that the assumption of homoscedasticity was met, and heteroscedasticity was not an issue of concern in the regression model.

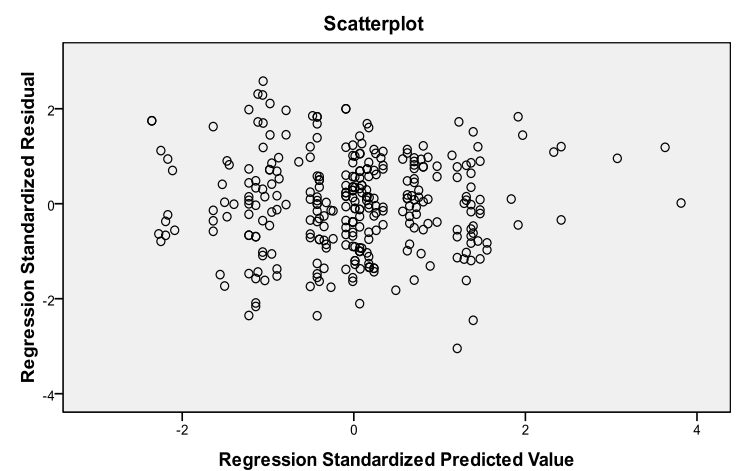

Figure 3. Standardised Residuals for the Multiple Regression Data

Linearity of the data was determined by examining the relationship between the five predictor variables and assessment practices. The obtained correlation coefficients in the multiple regression model in Table 3 highlight a statistically significant relationships as in model 1 (.469) and model 2 (.480). The probability of the correlation coefficient in model 2 of Table 3 is .043 which is less than the critical level $(p<.05)$. The null hypothesis was rejected to conclude that a linear relationship existed between the variables. The bivariate correlations in the correlation matrix (Table 1) have significant relationships to reflect linearity of the data. This also highlights that there were no great concerns of multicollinearity in the data set. The significant correlation coefficients in the correlation matrix in Table 1 show that assessment practices of the academic staff are significantly correlated with specialisation $r=.131$ ( $p<.05,313)$, academic levels $r=.469(p<.01,313)$, and assessment-based training $r=.121(p<.05,313)$. Other statistically significant correlations in the correlation matrix table include academic levels and specialisations $r=.144(p<.05,313)$, and assessment-based training with university $r=.404(p<.01,313)$. 
Table 1. Correlation Matrix of Five Predictors and Assessment Practices

\begin{tabular}{lllllll}
\hline Variables & \multicolumn{1}{c}{1} & 2 & 3 & 4 & 5 & 6 \\
\hline 1. Assessment & 1.000 & & & & & \\
2. University & .101 & 1.000 & & & & \\
3. Specialisation & $.131^{*}$ & .033 & 1.000 & & & \\
4. Academic Levels & $.469^{* *}$ & .001 & $.144^{*}$ & 1.000 & & \\
5. Class Size & .027 & .075 & -.008 & -.016 & 1.000 & \\
6. Assessment-based & $.121^{*}$ & $.404^{* *}$ & .035 & .044 & .000 & 1.000 \\
training & & & & & & \\
\hline
\end{tabular}

Note: $* * p<.01, * p<.05$

The outliers in the data were checked using both the univariate and multivariate multiple regression procedures. The scatter plot for the regression standardised residuals (Figure 3) shows that there existed some outliers in the data set. The studentized residuals were used to check the univariate outliers for the dependent variable using the z-scores computed based on the data for all the cases while the multivariate outliers were checked using mahalanobis distance. 8 cases were selected as outliers in the data set.

\section{Results}

According to the descriptive results from the multiple regression analysis universities $(\mathrm{M}=$ $.313, \mathrm{SD}=.4645)$, area of specialisation $(\mathrm{M}=.096, \mathrm{SD}=.295)$, academic levels $(\mathrm{M}=.061, \mathrm{SD}=$ $.239)$, class size $(\mathrm{M}=.345, \mathrm{SD}=.476)$, and assessment-based training $(\mathrm{M}=.546, \mathrm{SD}=.499)$ were analysed. The results of ANOVA in Table 2 reveal that the probability of the $F$ statistics (46.331) of the regression relationship for the variables of academic levels and assessment-based training, the $p$ values was both .000 , which is less than the critical level $(p<.001)$. The ANOVA results of multiple regression analysis in Table 2 highlight a statistically significant relationship between the two predictor variables and assessment practices $(F[2,310]=46.331, p<.001)$. The results rejected the null hypothesis that there is no relationship between the predictor variables and the dependent variable.

Table 2. ANOVA Table for Multiple Regressions

\begin{tabular}{llccccc}
\hline Model & Sum of Squares & $d f$ & Mean Square & $F$ & Sig. \\
\hline 1 & Regression & 7.930 & 1 & 7.930 & 87.660 & $.000^{* \mathrm{a}}$ \\
& Residual & 28.132 & 311 & .090 & & \\
& Total & 36.062 & 312 & & & \\
\hline 2 & Regression & 8.299 & 2 & 4.149 & 46.331 & $.000 *^{\text {b }}$ \\
& Residual & 27.763 & 310 & .090 & & \\
& Total & 36.062 & 312 & & & \\
\hline
\end{tabular}

Note: $* p<.001$, a. Predictors: (Constant), academic levels, b. Predictors:

(Constant), academic levels, assessment-based training

The multiple regression summary model results in Table 3 show that there are two statistically significant variables when all the predictor variables were analysed in the step-wise regression model. Out of the five factors which were analysed as predictor variables of assessment practices, the two significant variables yielded an $R$ of .480 and $R^{2}$ of .230 that were statistically significant at $p<.05 ;(F$ $[2,310]=4.122, p=.043)$ as in Table 3 . The combined model that yielded the $R^{2}$ of .230 included academic levels and assessment-based training. Three insignificant variables which were excluded from the model include; type of university, specialisation, and class size. The adjusted $R^{2}$ of .225 in Table 3 indicates that about $22.5 \%$ of the variability in the academic staff's assessment practices is accounted for by the academic levels and assessment-based training. The Durbin-Watson results of 1.786 are within the required range $(1-4)$ which show that there was no autocorrelation, or, there was independence of errors in the data which was analysed. 
Table 3. Multiple Regressions Summary Model

\begin{tabular}{|c|c|c|c|c|c|c|c|c|c|c|}
\hline \multirow[b]{2}{*}{$\frac{\overline{0}}{\overline{0}}$} & \multirow[b]{2}{*}{$\mathrm{R}$} & \multirow[b]{2}{*}{$\begin{array}{c}\mathrm{R} \\
\text { Square }\end{array}$} & \multirow[b]{2}{*}{$\begin{array}{l}\text { Adjusted } \\
\text { R Square }\end{array}$} & \multirow[b]{2}{*}{$\begin{array}{c}\mathrm{R} \\
\text { Square } \\
\text { Change }\end{array}$} & \multicolumn{6}{|c|}{ Change Statistics } \\
\hline & & & & & $\begin{array}{l}\text { Std. Error } \\
\text { of the } \\
\text { Estimate }\end{array}$ & $F$ & $d f 1$ & $d f 2$ & Sig & $\begin{array}{l}\text { Durbin- } \\
\text { Watson }\end{array}$ \\
\hline 1 & $.469^{\mathrm{a}}$ & 220 & 217 & 220 & 301 & 87.660 & 1 & 311 & $.000 *$ & \\
\hline 2 & $.480^{\mathrm{b}}$ & .230 & .225 & 010 & 299 & 4.122 & 1 & 310 & $.043^{*}$ & 1.786 \\
\hline
\end{tabular}

Note: ${ }^{*} p<.05$, a. Predictors: (Constant), academic levels, b. Predictors: (Constant), academic levels, assessment-based training

From the results of the regression coefficients the standardized coefficients highlight that the two significant predictive variables in the model, academic levels (.465) have the strongest effect on the dependent variable followed by assessment-based training (.101). The observed standardised beta values or the size of influence indicate that the greatest influence upon the dependent variable was from academic levels $(\beta=.465, p<.001)$, followed by assessment-based training $(\beta=.101, p<.05)$ (Table 4). The results of the coefficients for multiple regression show that the two statistically significant predictive variables have a significant contribution to the academic staff's assessment practices. The tolerance revealed in the combined model of academic levels and assessment-based training which were the significant predictors of the assessment practices among university academic staff is .998. The Variance Inflation Factor (VIF) for both academic levels and assessment-based training is 1.002 (Table 4). There is no tolerance score below .1 and all the VIF scores are beneath 10 which are the relative threshold levels to highlight multicollinearity in the data.

Table 4. Regression Coefficients and Results of Significant Tests for the Final Model

\begin{tabular}{|c|c|c|c|c|c|c|c|c|}
\hline \multirow{2}{*}{\multicolumn{2}{|c|}{ Model }} & \multicolumn{2}{|c|}{$\begin{array}{l}\text { Unstandardized } \\
\text { Coefficients }\end{array}$} & \multirow{2}{*}{$\begin{array}{l}\text { Standardized } \\
\text { Coefficients } \\
\text { Beta }\end{array}$} & \multirow[b]{2}{*}{$\mathrm{t}$} & \multirow[b]{2}{*}{ Sig. } & \multicolumn{2}{|c|}{$\begin{array}{c}\text { Collinearity } \\
\text { Statistics }\end{array}$} \\
\hline & & $\mathrm{B}$ & Std. Error & & & & Tolerance & VIF \\
\hline \multirow[t]{2}{*}{1} & (Constant) & 3.283 & .018 & & 187.166 & $.000 * *$ & \multirow[b]{2}{*}{1.000} & \multirow[b]{2}{*}{1.000} \\
\hline & Academic Levels & .667 & .071 & .469 & 9.363 & $.000 * *$ & & \\
\hline \multirow[t]{3}{*}{2} & (Constant) & 3.315 & .023 & & 141.535 & .000 & \multirow{3}{*}{$\begin{array}{l}.998 \\
.998\end{array}$} & \multirow{3}{*}{$\begin{array}{l}1.002 \\
1.002\end{array}$} \\
\hline & Academic Levels & .660 & .071 & .465 & 9.312 & $.000 * *$ & & \\
\hline & $\begin{array}{l}\text { Assessment-based } \\
\text { training }\end{array}$ & .069 & .034 & .101 & 2.030 & $.043 *$ & & \\
\hline
\end{tabular}

Note: $* P<.05, * * P<.001, R^{2}$ for the final model was .230

According to the results of the regression coefficient in Table 4, the slope associated to academic level is .660 suggesting that the academic staff's rise in academic levels leads to an increase of .660 units in their assessment practices than when they have not risen academically. The slope coefficient for assessment-based training is .069 suggesting that assessment-based training has an associated increase of .069 units in academic staff's assessment practices when academic levels are kept constant. On the other hand, it can also be interpreted that each unit increase in academic levels $(\beta=.660, p=.000)$ leads to a $66.0 \%$ increase in the academic staff's assessment practices. For the beta coefficient of assessment-based training ( $\beta=.069, p=.043)$, every unit increase in assessment-based training yields an increase of $6.9 \%$ in the academic staff's assessment practices. It can be drawn from the findings of this study that the academic staff who have high academic levels and have undertaken assessmentbased training have higher assessment practices than those who have not developed academically and taken an assessment-based training.

\section{Discussion}

Five factors were included in the multiple regression models as predictor variables to the assessment practices of the academic staff. Among the included five predictor variables in the model, only two variables were statistically significant; academic levels and assessment-based training. These findings are similar to those which revealed that assessment practices of teachers are predicted by their academic levels and the assessment training they had attained (Khalid et al., 2012; Noordin \& Jusoff, 
2009). The results of multiple regressions reveal that academic levels contribute more to the academic staff's assessment practices than assessment-based training but, all are significant predictors. These results support the findings of the study which highlighted that the higher the academic qualification, the higher the assessment practices and teaching skills (Susuwele-Banda, 2005).

Assessment-based training has also been identified to be a significant predictor of the assessment practices of the university academic staff. This finding supports the findings which highlighted that assessment-based training improves assessment practices of academic staff (Jere, 2000; Stiggins, 1999; Susuwele-Banda, 2005). The training programmes undertaken by the university academic staff would help them to improve their assessment competencies and skills (Harlen, 2005; Zhang \& BurryStock, 2003). Again, the findings of this study which have found that assessment-based training is a significant predictor of university academic staff assessment practices have supported the finding of Phamotse et al. (2011) and, Zhang and Burry-Stock (2003) who highlighted that academic staff's ability to execute assessment tasks largely depends on their levels of training in undertaking student assessments. It can be noted from the results of this study that assessment-based training undertaken by the academic staff is relevant for their practice, and if not undertaken, it can affect the way they assess students. According to Tindal and Haladyna (2002) they mentioned that academic staff who are lacking adequate assessment skills are not expected to effectively assess the students they teach. If they tend to assess effectively, then, their major aim of assessing concentrates on the learning outcomes rather than improving the learning process (Tindal \& Haladyna, 2002). It is concluded that if academic staff lack proper assessment-based training in the various assessment components such as designing, administering, interpreting, and applying the results got from the assessments they are expected to have poor assessment practices (Kanjee \& Sayed, 2008; Masole, 2011).

Some of the hypothesised predictor variables of the academic staff's assessment practices were found to be insignificant such as the type of university, class size, and specialisations. These findings also support findings of other studies which revealed that class size had no significant effect on the teachers' assessment practices (Duncan \& Noonan, 2007). Though this is the finding of the study, generally smaller class sizes have been preferably mentioned to be better than larger classes in number when teaching and assessing students (ATA, 2003; Black \& Wiliam, 1998; Susuwele-Banda, 2005). Also, the finding of this study contradict with findings of Koloi-Keaikitse (2012) who articulated that there are differences in the assessment practices of academic staff according to their class size and subject area or, specialisation. These results might be different from those of this study because the study was conducted in schools while the current study has been done on academic staff in universities.

\section{Recommendations and conclusion}

From the findings of this study it can be recommended that universities should provide assessment-based training to their academic staff to ensure that they have proper assessment practices to assess their students as effectively (Duncan \& Noonan, 2007; Harlen, 2005; Masole, 2009, 2011 Mertler, 1998). This is because studies have mentioned that most of the academic staff in institutions have inadequate competencies and skills in assessing students (Brookhart, 2003; Duncan \& Noonan, 2007; Guskey, 2003; Howie, 2006; Masole, 2011; Mertler, 2003; Stiggins, 2002, 1999; Stockking et al., 2004; Vandeyar \& Killen, 2007; Zhang \& Burry-stock, 2003). Academic staff who undertook assessment-based training at their degree or diploma levels, the courses they attained focused on large scale assessment which might not necessarily apply in universities (Gullickson, 1986; Stiggins \& Bridgeford, 1985). Assessment-based training programmes would help these academic staff to strengthen their competencies and skills in designing and using rubrics, become better in planning and constructing tests, improve on their grading expertise, be able to standardise tests, and to interpret assessment results appropriately. This would also help the students to enjoy fair assessments as they would be assessed adequately by the academic staff (Alkharusi, 2011, 2012; Koloi-Keaikitse, 2012). It can be concluded that universities ought to support their academic staff to rise in their academic levels and also, avail them with assessment-based training programmes. This is because academic levels and 
assessment-based training in this study have been noted to be significant predictors of academic staff's assessment practices.

\section{References}

Adams, E.L., \& Hsu, J.Y. (1998). Classroom assessment: Teachers' conceptions and practices in mathematics. School Science and Mathematics, 98(4), 174-180.

Alberta Teachers' Association [ATA]. (2003). Class size and its effect on learning. Retrieved from http://www.teachers.ab.ca/publications/reports/size.html

Alkharusi, H. (2011). Teachers' classroom assessment skills: Influence of gender, subject area, grade level, teaching experience and in-service assessment training. Turkish Science Education, $8(2), 39-47$. Retrieved from http://www.tused.org

Alkharusi, H. (2012). Educational assessment attitudes, competencies, knowledge, and practices: An exploratory study of Muscat teachers in the Sultanate of Oman. Journal of Education and Learning, 1(2), 217-232. http://dx.doi.org/10.5539/jel.v1n2p217

Baylor, C., Yorkston, K., Bamer, A., Britton, D., \& Amtamann, D. (2010). Variables associated with communicative participation in people with multiple sclerosis: A regression analysis. American Journal of Speech - Language Pathology, 19, 143-153.

Bennel, P., \& Molwane, A.B. (2008). Teacher supply and demand for Botswana primary and secondary schools: 2006-2016. Gaborone: Government Printer.

Black, P., \& Wiliam, D. (1998). Inside the black box: Raising standards through classroom assessment. Phi Delta Kappan, 80(2), 139-148.

Black, P., Harrison, C., Lee, C., Marshall, B., \& Wiliam, D. (2004). Working inside the black box: Assessment for learning in the classroom. Phi Delta Kappan, 86, 8-21.

Bol, L., Stephenson, P.L., O'Connell, A.A., \& Nunnery, J.A. (1998). Influence of experience, grade level, and subject area on teachers' assessment practices. Journal of Educational Research, 91, 323-330. http://dx.doi.org/10.1080/00220679809597562

Boston, C. (2002). The concept of formative assessment. Practical Assessment Research and Evaluation. Retrieved from http://PAREonline.net/getvn.asp?v=8\&n=9

Brookhart, S.M. (2003). Developing measurement theory for classroom assessment purposes and uses. Educational Measurement: Issues and Practice, 22(4), 5-25.

Cartwright, R., Weiner, K., \& Streamer-Veneruso, S. (2009). Student learning outcomes (SLO) assessment handbook. Montgomery County: Maryland Press.

Duncan, C.R., \& Noonan, B. (2007). Factors affecting teachers' grading and assessment practices. The Alberta Journal of Educational Research, 53(1), 1-21.

Earl, L.M. (2003). Assessment as learning: Using classroom assessment to maximize student learning. Thousand Oaks, CA: Corwin Press.

Ewell, P.T. (2009). Assessment, accountability, and improvement: Revisiting the tension. National Institute for Learning Outcomes Assessment, University of Illinois, Illinois.

Finn, D.J., Gerber, S.B., \& Boyd-Zarias, J. (2003). Answers and questions to class size: A state-wide experiment. American Educational Research Journal, 27(93), 557-577.

Garson, G.D. (1998). Cronbach's reliability analysis. North Carolina: North Carolina State University.

Gibbs, G., \& Simpson, C. (2004). Conditions under which assessment supports students' learning. Learning and Teaching in Higher Education, 1, 3-31.

Gipps, C. (1994). Beyond testing: Towards a theory of educational assessment. London: Falmer Press.

Gleim, J A., \& Gleim, R.R. (2003). Calculating, interpreting, and reporting Cronbach's alpha reliability coefficient for likert type scales. In Midwest Research Practice Conference in Adult, Continuing, and community Education. Ohio State: Ohio University.

Graue, E., Oen, D., \& Rauscher, E. (2007). Understanding how class size reduction and assessment shape education experiences. Wisconsin Centre for Education Research, University of Wisconsin, Madison. http://varc.wceruw.org/sage/Class\%20size\%20reduction\%20and\%20assessment\%20final.pdf 
Gullickson, A.R. (1986). Teacher education and teacher-perceived needs in educational measurement and evaluation. Journal of Educational Measurement, 23(4), 347-354.

Guskey, T.R. (1994). Making the grade: What benefits students? Educational Leadership, 14-19.

Guskey, T.R. (2003). How classroom assessments improve learning. Educational Leadership, 60(5), 6-11.

Harlen, W. (2005). Teachers' summative practices and assessment for learning - tensions and synergies. The Curriculum Journal, 16, (2), 207-223. http://dx.doi.org/10.1080/09585170500136093

Howie, S.J. (2006, March). Assessment for learning Strategies: Merging theory and practice within South Africa realities. A paper presented at the GDE Assessment for learning conference, Johannesburg, South Africa.

Jere, D.R. (2000). The challenges of school-based assessment in primary schools in Malawi. Education Measurement Issues and Practice, 19 (3), 45. http://dx.doi.org/10.1111/j.17453992.2000.tb00037.x.

Jones, V. (2006). How do teachers learn to be effective classroom managers? In C.M. Everton \& C.S. Weinstein (Eds), Handbook of classroom management: Research, practice and contemporary issues (pp. 887- 908). New York: Routledge.

Kanjee, A., \& Sayed, Y. (2008, March). Assessment and education quality in South Africa. A paper presented at the world 52nd Annual meeting of the Comparative and International Education Society, Teacher College Columbia University, New York.

Khalid, S., Irshad, M.Z., \& Mahmood, B. (2012). Job satisfaction among academic staff: A comparative analysis between public and private sector universities of Punjab, Pakistan. International Journal of Business and Management, 7(1), 127-137.

Koh, K.H. (2011). Improving teachers' assessment literacy through professional development. Teaching Education, 22, 255-276. http://dx.doi.org/10.1080/10476210.2011.593164

Koloi-Keaikitse, S. (2012). Classroom Assessment Practices: A survey of Botswana primary and secondary school teachers. (Unpublished doctoral dissertation). Ball State University, Muncie, Indiana.

Lindholm, J.A. (2009). Guidelines for developing and assessing student learning outcomes for undergraduate majors. Los Angeles: UCLA.

Locastro, V. (2001). Teaching English to large classes. TESOL Quarterly, 35(1), 493-496.

Marsh, P.A. (2007). What is known about student learning outcomes and how does it relate to the scholarship of teaching and learning? International Journal for the Scholarship of Teaching and Learning, 1(2), 1-12.

Masole, T.M. (2009, September). Implementing quality performance assessment in agriculture. A paper presented at the $35^{\text {th }}$ annual conference of AEAA Australia, Melbourne, Australia. http://www.iaea.info/documents/paper_4d73a42.pdf

Masole, T.M. (2011). Enhancing the quality of performance assessment in Agriculture in Botswana. (Unpublished doctoral dissertation). University of Pretoria, Pretoria.

Matovu, M., \& Ainol, M.Z. (2015). Self-perceived assessment competencies and practices among university lecturers, Emerald Journal of Applied Research in Higher Education, 7(2).

McDowell, L., Wakelin, D., Montgomery, C., \& King, S. (2011). Does assessment for learning make a difference? The development of a questionnaire to explore the student response. Assessment and Evaluation in Higher Education, 36(7), 749-765. http://dx.doi.org/10.1080/02602938.2010.488792

McMillan, J.H. (2003). Understanding and improving teachers' classroom assessment decisionmaking: Implications for theory and practice. Educational Measurement: Issues and Practice, 22(4), 34-43.

Mertler, C.A. (1998, October). Classroom assessment practices of Ohio teachers. A paper presented at the 1998 annual meeting of the Mild-Western Educational Research Association, Chicago, Illinois.

Mertler, C.A. (2003). Pre-service versus in-service teachers' assessment literacy: Does classroom experience make a difference? (Unpublished doctoral dissertation). Bowling Green State University, Bowling Green, Ohio. 
Miller, D.C., Sen, A., \& Malley, L.B. (2007). Comparative indicator of education in the United States and other G-8 countries; 2006. (NCES 2007-006). National Centre for Education Statistics, Institute of Education Science, U. S. Department of Education. Washington, D. C.

Monk, D.H., \& Haller, E.J. (1993). Predictors of high school academic course offerings: The rule of school size. American Educational Research Journal, 30(1), 3-21.

Mundia, L. (2010). Implementation of SPN21 curriculum in Brunei Darussalam: A review of selected implications on school assessment reforms. International Education Studies, 3(2), 119-128.

Nicol, D.J., \& Macfarlane-Dick, D. (2006). Formative assessment and self-regulated learning: A model and seven principles of good feedback practice. Studies in Higher Education, 31(2), 199-218.

Noordin, F., \& Jusoff, K. (2009). Levels of job satisfaction amongst Malaysian academic staff: Asia social sciences. $\quad$ Retrieved from www.ccsenet.org/journal/index.php/ass/article/download/.../1614

Pellegrino, J., Chudowsky, N., \& Glaser, R. (2001). Knowing what students know: The Science and Design of Educational Assessment. Washington DC: National Academy Press.

Phamotse, T.I., Nenty, H.J., \& Odili, J.N. (2011). Training and Availability of Skills for Sustenance of Standard in Classroom Assessment Practices among Lesotho Teachers. International Journal of Scientific Research in Education, 4(3), 190-201.

Popham, W.J. (2004). Why assessment illiteracy is professional suicide. The Teaching for Meaning, $62(1), 82-83$.

Popham, W.J. (2009). Assessment literacy for teachers: Faddish or fundamental? Theory into Practice, 48(1), 4-11. http://dx.doi.org/10.1080/00405840802577536.

Reynolds, A., Reagin, M., \& Reinshuttle, K. (2001). Less is more: What teachers say about decreasing class size and increasing learning. American School Board Journal, 199(9), 30-32.

Rolheiser, C., \& Ross, J. (2000). Student self-evaluation-What do we know? Orbit, 30(4), 33-36.

Sato, M., Chung, R.R., \& Darling-Hammond, L. (2008). Improving teachers' assessment practices through professional development: The case of national board certification. American Educational Research Journal, 65(3), http://dx.doi.org/10.3102/0002831208316955

Scroggins, B. (2004). The teaching-learning cycle: Using student learning outcome results to improve teaching and learning: Workshop activities and resource materials. Modesto Junior College, California.

Stiggins, R.J. (1999). Evaluating classroom assessment training in teacher education programs. Educational Measurement: Issues and Practice, 18(1), 23-27.

Stiggins, R.J. (2001). The unfulfilled promise of classroom assessment. Educational Measurement: Issues and Practice, 20(3), 5-15.

Stiggins, R.J. (2002). Assessment crisis: The absence of assessment for learning. Phi Delta Kappan, 83(10), 758-765.

Stiggins, R.J., \& Bridgeford, N.J. (1985). The ecology of classroom assessment. Journal of Educational Measurement, 22(4), 271-286.

Stiggins, R.J., \& Conklin, N.F. (1992). In teachers' hands: Investigating the practices of classroom assessment. Albany: State University of New York Press.

Stockking, K., Jos-Jaspers, M.S., \& Erkens, G. (2004). Teachers' assessment of students' research skills. British Educational Research Journal, 30(1), 93-116.

Susuwele-Banda, W.J. (2005). Classroom assessment in Malawi: Teachers' perceptions and practices in mathematics. (Unpublished doctoral dissertation). Virginia Polytechnic Institute and State University, Virginia.

Swaffield, S. (2011). Getting to the heart of authentic assessment for learning. Assessment in Education: Principles, Policy and Practice, 18(4), 433-449.

Tabachnick, B.G., \& Fidell, L.S. (2007). Using multivariate statistics (5th edn.). Boston: Allyn and Bacon.

Tavakol, M., \& Dennick, R. (2011). Making sense of Cronbach's alpha. International Journal of Medical Education, 2, 53-55.

Timperley, H., Wilson, A., Barrar, H., \& Fung, I. (2007). Teacher professional learning and development: Best evidence synthesis iteration (BES). Auckland, University of Auckland. 
Tindal, G., \& Haladyna, T.M. (2002). Large-Scale assessment programs for all students - validity, technical adequacy and implementation. New Jersey: Lawrence Erlbaum Associates Publishers Inc.

Vandeyar, S., \& Killen, R. (2007). Educators' conceptions and practice of classroom assessment in post-apartheid South Africa. South African Journal of Education, 27(1), 101-115.

Welsh, C.L. (1989). The relationship of school size to student achievement. (Unpublished doctoral dissertation). University of Kansas, Kansas.

Zhang, Z., \& Burry-Stock, J.A. (2003). Classroom assessment practices and teachers' self-perceived assessment skills. Applied Measurement in Education, 16(4), 323-342. http://dx.doi.org/10.1207/S15324818AME1604_4 